\title{
Global citizenship and new literacies providing new ways for social Inclusion
}

\author{
New Literacies
}

\author{
Clarisse O. Lima \\ Scott W. Brown
}

\begin{abstract}
We are living in a society where information is the most valuable asset. However, the gigantic amount of information available daily creates the need for people to acquire new skills to locate, analyze and communicate this information. This comparative study utilizes an online survey to define global citizenship traits and identify the use of information and communication technologies (ICT), in 258 high school students in Brazil and the U.S. Differences in gender were also examined and the results inform how globalization, citizenship and ICT use are reflected in the self perceptions of boys and girls from both countries. The concept of new literacies is defined as the skills that individuals must posses to participate effectively and to be included in the diverse society we live. Keywords: New literacies, ICT, global citizenship, social inclusion
\end{abstract}

\section{A nova literácia promovendo cidadania global de alunos brasileiros e americanos}

\section{Resumo}

Estamos vivendo em uma sociedade onde a informação é o bem mais valioso. Entretanto, a enorme quantidade de informação disponível diariamente cria a necessidade das pessoas adquirirem novas habilidades para localizar, analisar e transmitir essa informação. Esse estudo comparativo utiliza um questionário on-line para definir características de cidadania global e identificar o uso das tecnlogias da informação e comunicação (TICs) em 258 alunos no Brasil e nos Estados Unidos. Diferenças de gênero também foram examinadas e os resultados informam como globalização, cidadania e uso das TICs estão refletidas nas percepções de meninos e meninas nos dois países. O conceito 'nova literácia' envolve as habilidades que os indivíduos devem possuir para participarem efetivamente e estarem incluídos nessa sociedade tão diversa e desigual em que vivemos.

Palavras-chave: Nova literacia, TIC, cidadania global, inclusão social

\section{El nuevo desarrollo de la lectura y la escrita promoviendo ciudadanía global de alumnos brasileños y americanos}

\section{Resumen}

Estamos viviendo en una sociedad donde la información es el bien más valioso. Pese a eso, la gran cantidad de información disponible diariamente crea la necesidad de que las personas adquieran nuevas habilidades para localizar, analizar y transmitir esa información. Este estudio comparativo utiliza un cuestionario online para definir características de ciudadanía global e identificar el uso de las tecnologías de la información y comunicación (TICs) en 258 alumnos en Brasil y en Estados Unidos. También fueron examinadas diferencias de sexo y los resultados informan como la globalización, la ciudadanía y el uso de las TICs están reflejados en las percepciones de varones y niñas en los dos países. El concepto de nuevo desarrollo de la lectura y la escrita envuelve habilidades que los individuos deben tener para participar efectivamente y estar incluidos en esa sociedad tan diversa y desigual en la que vivimos. Palabras clave: Nuevo desarrollo de la lectura y la escrita, TIC, ciudadanía global, inclusión social. 
The multiple dimensions of globalization bring with it both positive and negative consequences for the world, its countries and individuals. It is argued that the effects of globalization produce inequalities, excluding nations and people from the dominant system. Several factors contribute to the development of global citizens. The emergence of Information and Communication Technologies (ICT) is seen as one of the leading forces of globalization, connecting people through expansive networks that have flattened the world. Education is the driving force leading to the economic, political, cultural, and social development of a country. Citizenship encompasses the rights and responsibilities an individual has within his/her community and society. But in a globalized world the notion of an educated person and the concept of citizenship are being redefined, and both education and citizenship play an important role in equipping individuals with the necessary knowledge and skills to be active participants in society, in essence to be global citizens. It is up to us as individuals to address both the positive and negative challenges that globalization brings; efforts must be put forth to include those excluded.

This investigation expands the concept of the digital divide beyond focusing on access to technology to investigating how those who have access to ICT are using these technologies and are being excluded or included in their local societies and across the globe. Therefore, the purpose of this study is to identify how students from a developing and a developed country (Brazil and the U.S. respectively), who have access to ICT, are currently using them. Traits of global citizenship and socially valued ways of ICT use are delineated and examined with the goal of identifying the characteristics of those who are socially excluded and socially included in the globalized world. Results inform how globalization, education, citizenship and ICT use are reflected in the self perceptions of students from both countries. These traits have implications related to their readiness to act as global citizens, think critically, make informed decisions, and be active participants in the global society.

\section{Introduction}

Munck (2005) defines social exclusion as the social counterpart of globalization. The main question that sets the tone of discussion in his book on this topic is: how can we move beyond social exclusion to a form of empowerment that could lead to genuine social transformation? Friedman (2005) defines three great eras of globalization that have been historically happening in the world by means of its dynamic forces being key agents of change. Countries appear as the key agent of change in the first era; in the second era companies took the lead as the dynamic forces globalizing and finally in the third era, which is the one we entered a few years ago, the dynamic force globalizing the world "is the newfound power of individuals to collaborate and compete globally" (Friedman, 2005, p. 10).

Enlightened by Munck's question and Friedman's assumption, it becomes clear that the path that leads to social change in the era of globalization is to be drawn by individuals. It is up to the individual to use its knowledge and skills (power) in order to promote a more just and equal world for all its citizens, lessening discrimination and marginalization - that is, including the excluded.

The primary purpose of this study was to identify how middle and high school students from two economically divergent countries perceive themselves as global citizens and how they use ICT in social ways. In order to define the scenario for this cross-cultural research it is important to analyze the following set of questions:

- How globalization is influencing the lives of people all over the world and specifically in Brazil and the U.S.?

- How the notion of citizenship is being affected by the knowledge-based society?

- How critical is ICT to promote social inclusion? and

- How prepared are students to live in a globalized world?

This investigation involves issues related to how to educate people, crediting education as key for the development of individuals, communities and societies. 
The World Bank Atlas states that education creates "choices and opportunities for people, reduces the twin borders of poverty and disease, and gives a stronger voice in society" (The World Bank, 2003, p. 16). Additionally, Narayan, Patel, Schafft, Redemacher, and Koch-Schulte (2000) argue that lack of access to education and essential resources drives poor families out of the system and "[i]n so doing, they may be denied the tools necessary for civic participation and informed engagement with formal institutions" (p. 126).

\section{New Literacies}

The notion of an educated person has changed as a result of the globalized era. New concepts continually, and rapidly, arise as new knowledge, attitudes, behaviors and skills have to be mastered to guarantee a position in the competitive and interconnected world. Knowing about world problems and how they impact lives across the globe is an important aspect to inform the attitudes taken by individuals and how they behave with others. Being a more critical, responsible and participative citizen propels one to make better informed decisions. Using technology in an effective way is a skill that becomes necessary for everyone to operate and feel included in the society. The construct new literacies is seen as a powerful concept that redefines what it means to be literate in the 21 st century.

Gee (2000) argues the new times bring new dominant discourses, new literacies, which are "discourses that give one access to power, social goods, and relative freedom from oppression in our new capitalist, global, high-tech world, for poor and rich alike" (p. 4I3). According to Leu, Castek, Coiro, Gort, Henry and Lima (in press), one of the defining characteristics of the new literacies perspective is that it is central to full civic, economic, and personal participation in a globalized community, and for that reason, it is critical to the education of all students. Therefore, new skills and strategies - new literacies have to be mastered in order to process these new kinds of information in a socially meaningful way.

According to Warschauer (2003) the importance of the use of technology to enhance literacy and education is not guaranteed by the availability of hardware, software and connections. He states that the "deployment of technology toward greater equality, inclusion and access ... will depend in large part on the mobilization of learners, educators, and communities to demand that technology be used in ways that serve their interests" (p. I52). Many technological advances that were not even envisioned 20 years ago such as the Internet tools of e-mail, listservs, chat rooms, forums and instant messenger, are now providing new opportunities for direct communication with students and teachers in other countries (Smith, 2002). This provides educators a tool for incorporating instructional strategies toward increasing global awareness. It is important to emphasize the need to educate students who are prepared to fully operate in the globalized world.

For the purpose of this study a global citizen is defined as a person who possesses the following characteristics: (I) awareness and concern about globalization and its impacts on individuals and the world; (2) awareness about rights and responsibilities of a citizen; (3) meaningful and socially valued use of ICT; and (4) basic skills needed to fully operate and participate in a globalized society (new literacies).

In summary, the understanding of social exclusion as one of the effects of globalization, the need for implementation of strategies to prepare young people to live in a globalized society, and the importance of using ICT in socially valued ways with the intention of diminishing inequalities in the world, constitute the assumptions of global citizenship that this study set out to investigate in a developed and a developing country. The Social Inclusion Model (SIM) was created as a framework to investigate the concept of a global citizen, one who uses ICT in socially valued ways for inclusion and social development. SIM provides the framework to investigate individuals on: (a) the extent they are aware of and concerned about world current and important issues, (b) how they use technology, and (c) how they see themselves as possessing the skills necessary to act as global citizens? The components that form the SIM were collected in a self-report web-based survey, measuring participants' Knowledge, Attitudes and Behaviors (KAB) towards 
global citizenship. Differences in KAB scores, as well as quantity and purpose of access to ICT, were contrasted within the two countries and within gender.

\section{Methodology}

Students attending middle and high school were chosen to be the participants of this investigation because of their status as the ones who are being educated to build their lives in a global world. The online survey called 'Global Citizenship' was created based on the SIM's framework with the purpose of identifying participants' self-reported knowledge, attitudes and behaviors (KABs) with respect to global citizenship and ICT use. Investigating these characteristics is important because the results can provide a profile of how students perceive themselves as global citizens, as well as inform further research on educational strategies and practices that need to be reinforced in order to provide more opportunities for students to be critical, skilled and participative citizens in the globalized world in which we live.

\section{Participants}

Students were recruited through the teachers and administrators in their schools. Whole classes of students from urban school systems in the U.S. and Brazil served as the population based of this sample. A total of 258 students responded to the survey, $57 \%$ from Brazil and $43 \%$ from the U.S. Fifty-two percent of the participants were boys and $48 \%$ girls. The majority of the participants reported being 14 or 15 years-old (47\%). With regards to Internet use, in Brazil $83 \%$ of the participants reported having Internet access at home; in the U.S. this number was $92 \%$. Brazilian students indicated accessing the Internet at school more than their American counterparts. Twenty-seven percent of Brazilian students informed accessing it at least three times a week, while the same amount of access per week was informed only by $16 \%$ of the American students. Interestingly, the same percentage of students in the two countries $(60 \%)$ reported everyday use of the Internet out of school.

\section{Instrument}

The Global Citizenship Survey was designed to measure the participants' $\mathrm{KABs}$ on the following traits: (I) globalization and its impact in the world; (2) citizenship rights and responsibilities in a globalized society; (3) resourceful usage of ICT; and (4) the acquisition of the new literacies needed to use ICT. Three scales (one for Knowledge, one for Attitudes and one for Behaviors) were developed. Each scale comprised statements to be classified by the students according to their level of agreement in a 5-point Likert scale (from strongly disagree to strongly agree).

The items in the globalization category focused on sub-topics of environmental issues, sustainable development, world politics, economy, human rights, health, war and terrorism and poverty (Narayan et al., 2000; The World Bank, 2003). Some examples of $K A B$ statements for the globalization category are:

- Knowledge - I am aware of what is currently happening in the world;

- Attitudes - Globalization causes extreme poverty and hunger in the world;

- Behaviors - I read about international politics.

The citizenship category contained items involved aspects such as respect for others, diversity, feeling of belonging, democracy (vote), social justice, equity, sense of identity and multiculturalism (Banks, 2003; Jones, 2004). Some examples of KAB statements for the citizenship category are:

- Knowledge - I know what my roles and rights are as a citizen;

- Attitudes - It is important to communicate with people from different cultures;

- Behaviors -.I volunteer time to work for other's benefit.

The ICT category contained items related to technology for improving quality of life, use of computers to communicate, use of the Internet, access - digital divide - and social inclusion (United Nations, 2004; Warschauer, 2003). The sub-topics related to critical thinking, identifying important problems, conducting research on the Internet, analyzing useful and reliable information, synthesizing information to solve problems and communicating 
solutions to others grounded the items used to measure the new literacies category (Educational Testing Services, 2002; Leu, Kinzer, Coiro, \& Cammack, 2004; Warschauer, 1999). Some examples of KAB statements for the ICT category are:

- Knowledge - I know how to find the information I need on the Internet;

- Attitudes - Knowing how to use technology makes me feel more included in society;

- Behaviors - I use the Internet to communicate with friends.

The Global Citizenship Survey was administered during a school class period. Depending on the number of computers available, groups of students went to the computer lab to take the survey and were supervised by the media teacher or lab coordinator. Since the students responded the survey individually, the strategy on how to organize the students to go to the computer lab was held by the schools according to their own criteria. The average time spent per student taking the survey was 24 minutes.

\section{Results}

The $K A B$ scales were analyzed in order to identify different patterns on students from the two contrasting countries. Additionally, some traits that characterize a global citizen such as knowledge of a foreign language, usage of the Internet to be informed about current events in the world, communication with people from other countries and expressing opinions about things, were also analyzed. Interesting contrasts between the countries and gender were observed.

\section{Global Citizenship KABs by Country and Gender}

Scores were generated from students' answers to the Global Citizenship Survey, after Factor Analyses were conducted on the items of each one of the Knowledge, Attitudes and Behaviors scales. There were five resulting factors: two for the Knowledge scale (Awareness of international issues and Knowledge of new literacies of the Internet); one for Attitudes scale (Attitude toward global citizenship); and two for the Behavior scale (Caring about others and Reading about international issues). Each score of the five factors served as a dependent variable for multivariate analyses.

The analysis conducted to identify differences between students in the two countries indicated that Brazilian and American students differ significantly in two factors: attitudes towards global citizenship and caring about others. Students in Brazil presented higher scores in attitudes towards global citizenship when compared to American students. However, when considering the caring about others factor, Americans' scores outperformed Brazilians, suggesting that students in the U.S. show a tendency to be more concerned with others than students living in a developing country.

Statistically significant gender differences were found on the factor Care About Others, which included items related to supporting social projects, volunteer work and helping people in need. Girls demonstrated higher scores than boys, what may be due to character traits most frequently observed in girls of being more caring and emotional and boys being more competitive (Gilligan, as cited in Shields \& Bredemeier, 1995; Halpern, 2000). The scores of awareness of international issues and attitudes towards global citizenship were also higher for girls, although not statistically significant.

This finding suggests that both sexes' Knowledge, Attitudes and Behaviors related to being a global citizen are similar, which indicates that in the future both men and women will present equal knowledge, attitudes and behaviors regarding their position as global citizens in the world. Especially for women, this finding can bring more opportunities and empowerment to become more participative in societies and, consequently, diminish existing discrimination and prejudice against them. This result strengthens the importance of girls' education and global citizenship as a vehicle for the world's welfare, which constitutes a key item in the actual agenda of governments, institutions and organizations when discussing about the future of the world, especially the developing world (Save the Children, 2005; UNICEF, 2005). 


\section{Global Citizenship Traits and ICT Use by Country and Gender}

The majority of Brazilian students (72\%) reported speaking a foreign language, whereas only $29 \%$ of the Americans indicated that they speak a foreign language. Interesting results were found about the difference in the purposes of why students in the two countries would like to learn another language. In Brazil $50 \%$ of the students justified this willingness as related to having a better job. But, in the U.S. the majority of students pointed out communicating with and understanding people from other cultures as the two main reasons for learning other languages ( $42 \%$ and 19\% respectively).

The Internet was indicated as the most used resource to do coursework in both countries, by $79 \%$ of Brazilians and $62 \%$ of Americans. When asked about the websites they visit, more Brazilians indicated visiting websites from other countries and in another language than Americans ( $41 \%$ and $5 \%$ respectively). Fifty two percent of students in Brazil reported using the Internet to communicate with people from other countries at least sometimes, while only $21 \%$ of students in the U.S. indicated they performed this activity. The resource reported as used the most to obtain information about current events in the world was the TV in both countries (56\% for Brazilians and $64 \%$ for Americans); the second most popular resource was the Internet, with $22 \%$ of students in Brazil and 19\% of students in the U.S. using it to get up to date information about the world.

Brazilian students reported higher frequencies than Americans on using the Internet to express their opinions out of school $(25.5 \%$ and $15.3 \%$ respectively), which may indicate that they are more likely to share their opinions with others, characterizing good aspects related to participation in the society supporting global citizenship. Informed by these results, we can argue that Brazilian students are more likely to present global citizenship traits by their openness to the world using communication tools effectively.

An interesting finding related to online activity was that of going on websites and leaving their opinions was indicated by girls more often than boys at school
( $9.8 \%$ of girls and $3.7 \%$ of boys) and out of school ( $23.6 \%$ of girls compared to $18.8 \%$ of boys). This finding reinforces previous research indicating that girls' have a tendency to use the Internet as a means of communication and therefore, emphasizing this tools' socially valued use. As a general trend more girls reported getting news from the Internet both at school and out of school compared to boys.

\section{Conclusions}

Findings from this investigation indicate that the Social Inclusion Model provided an adequate framework to assess global citizenship characteristics in middle and high school students within a crosscultural perspective. The assessment methodology revealed the existence of differences in knowledge, attitudes and behaviors about being a global citizen by students in Brazil and in the U.S., as well as differences between boys and girls. Brazilians demonstrated a higher inclination towards being global citizens when compared to Americans regarding their scores in attitudes towards global citizenship and using more the Internet for communication purposes. However, when observing another important aspect that describes a global citizenship attribute, which is caring about others, Americans scored higher than Brazilians.

Differences and inequalities are issues that true global citizens are aware of and would like to see changed, and according to Noddings (2005) global citizens are tolerant and exercise solidarity. Therefore, the significant differences found in this study between girls' and boys' behavior concerning caring about others, suggests that girls showed a higher tendency and more characteristic traits of being global citizens than boys. Additionally, girls reported visiting news websites more than boys, as well as visiting websites where they could write their opinion about things. Girls also reported more use of the Internet as a communication tool, such as using it for e-mail, IM and communication with people from other countries, than boys. This finding combined with no significant gender differences found in the other factors of global citizenship, brings 
hope that in the future, females will be more empowered to have more opportunities to participate in societies and contribute more effectively for world's welfare and development.

In regards to frequency of access to the Internet, Brazilians and Americans described similar patterns. This suggests that when provided the opportunity of accessing ICT, students in Brazil are not falling behind students in the U.S. in terms of quantity of use. This fact offers a more balanced scenario for comparison among the participants to measure purpose of access, which was the main goal of this study. The results collected regarding what students use the Internet for in both countries, showed that Brazilians use it more for communication and entertainment purposes (e.g., accessing social network communities and listening to music) while Americans use it more for school related work and buying things online. Exploring the opportunities that the Internet offers for communicating with other people is an aspect that characterizes a socially valued way of its use, and therefore can support global citizenship traits. This being said, it can be argued that Brazilians are using the Internet following global citizens' patterns in better ways than Americans, and therefore are moving towards a more included position in the globalized world.

In this investigation students from a developing country, demonstrated more characteristics of global citizens than their counterparts in the developed country. The results from this study support that, regardless the country's situation, developed or developing, individuals can be either included or excluded from their societies and the world, if access to ICT is not socially valued. It is not just because one has access to technology that this person would automatically be included in the society. Access must be purposeful in order to empower people and lead them to development and inclusion.

It is reasonable to argue that females would be privileged in the global economy (knowledge society), which depends upon information gathering and communication (UNICEF, 2005). In addition, girls may be more affective and establish more solidarity when communicating. From a global perspective, the developing economies do not permit females to have access to public and governmental positions, neglecting and denying opportunities of full participation in society for them, leading to unfulfilled economic potential for a nation (Save the children, 2005). Females need to be fully integrated in the society because they have the skills to operate and succeed, and this study provides data that supports this assumption and gives hope that women's current situation is going to change in the near future.

Social inclusion is not all about access. Just having access to technologies doesn't guarantee an individual or a country's inclusion in the globalized world. Individuals making purposeful and conscious use of the new literacies created by the global information age are the ones who are empowered to include the excluded.

Freire (1993) advocated that literacy acquisition was important, not only for an individual to learn how to read and write, but also for developing a consciousness of the social, political and economic contradictions that oppress the poor and those marginalized. This consciousness is by his definition, the method where individuals attain the knowledge of reality through common reflection and action; action that leads to freedom.

Analogous to Freire's arguments, the SIM presented in this study emphasizes that the acquisition of the new literacies is increasingly important to individuals living in the information age. More than that, being literate in the globalized world means using ICT in socially valued ways. Acquiring new literacy skills promotes individuals' empowerment leading to social inclusion and development across the globe.

\section{References}

Banks, J.A. (2003). Educating global citizens in a diverse world. New Horizons for Learning. Retrieved September 27, 2004 from http://www.newhorizons.org/strategies/ multicultural/banks2.htm

Educational Testing Services. (2002). Digital transformation: A framework for ICT literacy. New Continuum Publishing Company. 
Friedman, T. L. (2005). The world if flat: A brief history of the twenty-first century (Ist ed.). New York: Farrar, Straus and Giroux.

Gee, J.P. (2000). Teenagers in new times: A new literacy studies perspective. Journal of Adolescent \& Adult Literacy, 43(5), 4I 2-20.

Halpern, D. F. (2000). Sex differences in cognitive abilities. (3 ${ }^{\text {rd }}$ ed.). Mahwah, NJ: Lawrence Erlbaum Associates, Inc.

Jones, L. A. (2004). Teaching citizenship through multicultural education. Kappa Delta Pi Record, 40, 60-6I.

Lenhart, A., Madden, M. \& Hitlin, P. (2005). Teens and Technology: Youth are leading the transition to a fully wired and mobile nation. Washington, D.C.: Pew Internet \& American Life Project.

Leu, D.J., Jr., Castek, J., Coiro, J., Gort, M., Henry, L.A. \& Lima, C.O. (in press). Developing new literacies among multilingual learners in the elementary grades. In L. L. Parker (Eds.).Technology-mediated learning environments for young English learners: Connections in and out of school. Mahwah, NJ: Lawrence Erlbaum Associates.

Leu, D. J., Jr., Kinzer, C. K., Coiro, J., \& Cammack, D. W. (2004). Toward a theory of new literacies emerging from the internet and other communication technologies. In R. Ruddell and N. Urau (Eds.), Theoretical models and processes of reading (5th ed., pp. I568-16II). Newark, DE: International Reading Association.

Munck, R. (2005). Globalization and social exclusion: A transformationalist perspective. Bloomfield, CT: Kumarian Press, Inc.

Narayan, D., Patel, R., Schafft, K., Redemacher, A., \& KochSchulte, S. (2000). Can anyone hear us? Voices of the poor. New York, NY: Oxford University Press, Inc.
Noddings, N. (2005). Global citizenship: Promises and problems. In N. Noddings (Eds.), Educating citizens for global awareness (pp. I-2I). New York, NY: Teachers College Press.

Save the Children. (2005). State of the World's Mothers. Retrieved April 5, 2006 from http://www.savethechildren.org/ mothers/report_2005/images/SOWM_2005.pdf

Shields, D.L.L. \& Bredemeier, B.J.L. (1995). Character development and physical activity. Champaign, IL: Human Kinetics.

Smith, A. F. (2002). How global is the curriculum? Educational Leadership, 60, 38-4I.

The World Bank. (2003). The World Bank Atlas. Washington, D.C.: The World Bank Group.

UNICEF. (2005). Gender Achievements And Prospects In Education. Retrieved April 5, 2006 from http://www.unicef.org/ publications/files/GAP_Report_part I_final_I4_Nov.pdf

United Nations. (2004). World Youth Report 2003 - the global situation of young people. New York, NY: United Nations Department of Economic and Social Affairs.

Warschauer, M. (1999). Electronic literacies, language, culture and power in online education. Mahwah, NJ: Laurence Erlbaum Associates, Inc.

Warschauer, M. (2003). Technology and social inclusion: Rethinking the digital divide. Cambridge, MA: MIT Press.

Recebido em: 22/06/2007

Revisado em: 01/08/2007

Aprovado em: 22/08/2007

\section{Sobre os autores}

Clarisse O. Lima - Consultora em Tecnologia Educacional e Pesquisadora do NAPI (grupo de pesquisa certificado pelo CNPq) . Rio de Janeiro, Brasil.

Scott W. Brown - Professor do Departamento de Psicologia Educacional da Universidade de Connecticut.

\section{Acknowledgments}

The authors would like to acknowledge the valuable orientation and support received from Dr. Donald J. Leu (Educational Psychology Department) and Dr. Mark A. Boyer (Political Science Department) of the University of Connecticut, during the development of this research. 